\title{
Analysis of preterm deliveries below 35 weeks' gestation in a tertiary referral hospital in the UK. A case-control survey
}

\author{
Wei Yuan', Anne M Duffner'1, Lina Chen², Linda P Hunt³ ${ }^{3}$ Susan M Sellers ${ }^{4}$ and Andrés López Bernal*1
}

\begin{abstract}
Background: Preterm birth remains a major public health problem and its incidence worldwide is increasing. Epidemiological risk factors have been investigated in the past, but there is a need for a better understanding of the causes of preterm birth in well defined obstetric populations in tertiary referral centres; it is important to repeat surveillance and identify possible changes in clinical and socioeconomic factors associated with preterm delivery. The aim of this study was to identify current risk factors associated with preterm delivery and highlight areas for further research.
\end{abstract}

Findings: We studied women with singleton deliveries at St Michael's Hospital, Bristol during 2002 and 2003. 274 deliveries between 23-35 weeks' gestation (preterm group), were compared to 559 randomly selected control deliveries at term (37-42 weeks) using standard statistical procedures. Both groups were $>80 \%$ Caucasian. Previous preterm deliveries, high maternal age (> 39 years), socioeconomic problems, smoking during pregnancy, hypertension, psychiatric disorders and uterine abnormalities were significantly associated with preterm deliveries. Both lean and obese mothers were more common in the preterm group. Women with depression/psychiatric disease were significantly more likely to have social problems, to have smoked during pregnancy and to have had previous preterm deliveries; when adjustments for these three factors were made the relationship between psychiatric disease and pregnancy outcome was no longer significant. 53\% of preterm deliveries were spontaneous, and were strongly associated with episodes of threatened preterm labour. Medically indicated preterm deliveries were associated with hypertension and fetal growth restriction. Preterm premature rupture of the membranes, vaginal bleeding, anaemia and oligohydramnios were significantly increased in both spontaneous and indicated preterm deliveries compared to term controls.

Conclusions: More than 50\% of preterm births are potentially preventable, but remain associated with risk factors such as increased uterine contractility, preterm premature rupture of the membranes and uterine bleeding whose aetiology is unknown. Despite remarkable advances in perinatal care, preterm birth continues to cause neonatal deaths and long-term morbidity. Significant breakthroughs in the management of preterm birth are likely to come from research into the mechanisms of human parturition and the pathophysiology of preterm labour using multidisciplinary clinical and laboratory approaches.

\section{Background}

Preterm birth remains a major cause of perinatal mortality and morbidity and efforts to predict and prevent its occurrence are difficult because of our lack of under-

\footnotetext{
* Correspondence: a.lopezbernal@bristol.ac.uk

1 University of Bristol, Department of Clinical Science at South Bristol (Obstetrics and Gynaecology), St Michael's Hospital, Southwell St. Bristol, BS2 8EG. UK

Full list of author information is available at the end of the article
}

standing of the biochemical mechanism of labour and the multiplicity of medical and socioeconomic factors associated with preterm delivery [1]. The incidence of preterm birth (deliveries before 37 weeks' gestation) ranges from 6-8\% in Europe, Australia and Canada [2,3], to $9-12 \%$ in Asia, Africa and the United States [4,5]. Preterm birth is recognised as a worldwide problem responsible for more than $80 \%$ of neonatal deaths and more than $50 \%$ of long term morbidity in the surviving infants [6,7]. The inci- 
dence of preterm birth has remained relatively constant over the past three decades and there are worrying trends that it is on the increase $[5,8]$. It is important to know whether risk factors have changed over the years and to look for new clinical and socioeconomic risks. This information is necessary to guide further research in this area. Epidemiological studies have identified a clear association between preterm birth and previous preterm delivery [9], preterm premature rupture of the membranes [10] and maternal smoking during pregnancy [11]. However the association between preterm birth and other maternal and fetal complications of pregnancy is less consistent, due to social, ethnic and demographic differences amongst the populations studied [7]. In this study we have carried out a detailed comparison of preterm and term deliveries in a relatively homogeneous obstetric population attending a tertiary referral maternity hospital, to highlight areas where further research or intervention is needed in order to prevent preterm birth and improve perinatal outcome.

\section{Methods Study population}

This survey was done at St Michael's Hospital, Bristol. This is a tertiary referral maternity centre with approximately 5500 deliveries a year; preterm deliveries (under 37 weeks' gestation) accounted for approximately $8 \%$ of all births during 2002 and 2003. In this survey we have focused on deliveries between 23-35 weeks' gestation (3\% of all births) because these account for most of the perinatal mortality and morbidity and so improvements in management are likely to have a strong impact on neonatal outcome. We obtained lists of all deliveries below 35 weeks gestation from the hospital database for two complete years 2002 and $2003(\mathrm{n}=274)$. We used computer generated random numbers to draw separate samples from lists of all term babies delivered within each of the 2 years, using term: preterm ratios of 2:1 to increase power; 559 out of 8204 term babies were included. Gestational age was based either on certain dates or a dating scan. Antenatal care was undertaken by an obstetrician or community midwife or a combination of the two professionals and followed standard UK practice.

This study was approved by the Central \& South Bristol Research Ethics Committee.

\section{Statistical analysis}

Initial maternal and newborn information was taken from the hospital computer databases (STORK and Vermont Oxford Network). The hospital medical records of each delivery were retrieved and analysed in detail by a trained research midwife (AMD) using a structured proforma. Information recorded was anonymised by assigning a unique project number to each delivery. Data on maternal and fetal characteristics at birth were recorded, including maternal age and gestational age at delivery, ethnicity, gestational age at booking, complications of pregnancy and delivery, birth weight, Apgar score and baby gender. A wide range of potential risk factors smoking and drinking status before and during pregnancy, history of drug use, socioeconomic status, past obstetric history (including previous history of termination, miscarriage and preterm birth) were recorded. Maternal body mass index (BMI) at booking was calculated using weight $(\mathrm{kg}) /$ height $(\mathrm{m})^{2}$. The definition of lean was BMI $<20 \mathrm{~kg} / \mathrm{m}^{2}$ and obese $\mathrm{BMI} \geq 30 \mathrm{~kg} / \mathrm{m}^{2}$. Data was entered into a Microsoft excel 2003 database and imported into STATA version 10 for analysis.

Comparisons between cases and controls were made using standard statistical procedures. Continuous variables were summarised by mean (SD) except for gestational age, which was not normally distributed, where the median (range) was used instead. Means were compared using unpaired Student's t-tests. For categorical variables Chi-squared tests were used and two-tailed Fisher's Exact tests for $2 \times 2$ tables where expected frequencies were small. A $5 \%$ level of significance was used throughout. Multiple logistic regression was used to adjust for confounding factors and compute odd-ratios.

\section{Results}

The control and preterm groups had very similar ethnicity and maternal age but, as expected, multiple births were more common in the preterm group (Table 1). Eight of the multiple pregnancies were the result of assisted reproduction treatment (IVF). Since the obstetric management of multiple pregnancies differs from that of singleton pregnancies, we excluded all the multiple pregnancies from further analysis.

\section{Maternal age and BMI}

Previous reports have indicated that extremes of maternal age and low maternal weight predispose to preterm birth and we have confirmed that the incidence of preterm birth in women over 39 years of age remains significantly higher than in younger women (Table 2); however the proportion of teenage mothers in the two groups was similar. Both lean and obese mothers were more common in the preterm group (odds ratios 1.75 (95\% CI 1.02 to $3.01)$ and 1.41 (95\% 0.92-2.15) respectively; reference category was the normal BMI group), but the overall difference did not reach statistical significance (Table 2).

\section{Socioeconomic factors}

The proportion of women with at least one social problem (low income; poor housing; unsupported or single parent) was significantly higher in the preterm than in the control group (Table 2). Smoking before conception was 
Table 1: General characteristics of the study groups.

\begin{tabular}{|c|c|c|c|}
\hline & $\begin{array}{l}\text { Control ( } \geq 37 \text { weeks' } \\
\text { gestation) }\end{array}$ & $\begin{array}{l}\text { Preterm (<35 weeks' } \\
\text { gestation) }\end{array}$ & P value \\
\hline Number of deliveries & 559 & 274 & \\
\hline $\begin{array}{l}\text { Gestational age at delivery } \\
\text { (completed weeks) }\end{array}$ & Median 40 (Range 37 - 42) & Median 33 (Range 23 - 34) & Not Applicable \\
\hline \multicolumn{4}{|l|}{ Ethnicity } \\
\hline Caucasian & $464(83.0 \%)$ & $229(83.6 \%)$ & 0.46 \\
\hline Asian & $45(8.1 \%)$ & $17(6.2 \%)$ & \\
\hline African & $33(5.9 \%)$ & $22(8.0 \%)$ & \\
\hline Others & $17(3.0 \%)$ & $6(2.2 \%)$ & \\
\hline Mean maternal age (years) & $\begin{array}{l}28.8 \text { (SD 6.04) } \\
\text { (Range 15-44) }\end{array}$ & $\begin{array}{l}29.7 \text { (SD 6.46) } \\
\text { (Range16-46) }\end{array}$ & 0.045 \\
\hline \multicolumn{4}{|l|}{ Distribution of births } \\
\hline Singletons & $553(98.9 \%)$ & $228(83.2 \%)$ & $<0.001$ \\
\hline Twins & $6(1.1 \%)$ & $44(16.1 \%)$ & \\
\hline Triplets & 0 & $2(0.7 \%)$ & \\
\hline
\end{tabular}

not associated with preterm birth (data not shown); however the proportion of women who smoked during pregnancy was significantly higher in the preterm than in the control group. The proportion of smokers in women with and without social problems was $58.2 \%$ and $19.6 \%$, respectively. The proportions of women who consumed alcohol or admitted using any recreational drugs (cannabis, amphetamines, barbiturate, crack, cocaine, heroin, methadone, ecstasy) during pregnancy were similar in the control and preterm groups.

\section{History of previous pregnancies}

About $70 \%$ of women in both groups had been pregnant previously and more than $56 \%$ had had previous deliveries (Table 3). The proportion of women with a previous preterm delivery (between 20 and 37 weeks' gestation) in the preterm group was significantly higher than in the control group. Analysis of previous pregnancies under 20 weeks' gestation revealed that terminations of pregnancy were significantly more common in the preterm group; however the proportion of spontaneous miscarriages in the two groups was similar.

\section{Pre-existing medical conditions}

The most common pre-existing medical conditions in the control and preterm deliveries are listed in Table 4. Hypertension (blood pressure $>140 / 90 \mathrm{mmHg}$ ), psychiatric disorders and uterine abnormalities were significantly associated with preterm delivery. A history of cervical incompetence was found only in the preterm group. Multivariable analysis revealed that women with psychiatric disorders were significantly more likely to have social problems $(\mathrm{P}<0.001)$, to have smoked during pregnancy $(\mathrm{P}<0.001)$ and to have had previous preterm deliveries $(\mathrm{P}$ $=0.007)$. When adjustments were made for the effect of these three factors the relationship between psychiatric disorders and preterm birth was no longer significant (odds-ratio $[95 \% \mathrm{CI}]$ reduced from $1.6[1.1-2.4]$ to 1.2 [0.8-1.8])

\section{Complications of pregnancy}

The incidence of maternal, fetal and other complications of pregnancy is shown in Table 5. Episodes of threatened preterm labour were the most common maternal complication in preterm deliveries, and occurred almost exclu- 
Table 2: Demographic and socioeconomic parameters in singleton pregnancies.

\begin{tabular}{|c|c|c|c|}
\hline & $\begin{array}{l}\text { Control ( } \geq 37 \text { weeks' } \\
\text { gestation) }\end{array}$ & $\begin{array}{l}\text { Preterm }(<35 \text { weeks' } \\
\text { gestation) }\end{array}$ & P value \\
\hline Number of deliveries & 553 & 228 & \\
\hline $\begin{array}{l}\text { Median gestational age at } \\
\text { delivery (completed weeks) } \\
\text { and range }\end{array}$ & 40 (Range 37-42) & 33 (Range 23 - 34) & Not Applicable \\
\hline \multicolumn{4}{|l|}{ Maternal age } \\
\hline $\begin{array}{l}\text { Mean maternal age at delivery } \\
\text { (years) }\end{array}$ & $\begin{array}{l}28.8 \text { (SD 6.04) } \\
\text { (Range 15-44) }\end{array}$ & $\begin{array}{l}29.4 \text { (SD 6.69) } \\
\text { (Range16-46) }\end{array}$ & 0.24 \\
\hline$\leq 18$ years & $33(6.0 \%)$ & $13(5.7 \%)$ & \\
\hline $19-39$ years & $509(92.0 \%)$ & $199(87.3)$ & 0.002 \\
\hline$>39$ years & $11(2.0 \%)$ & $16(7.0 \%)$ & $\begin{array}{l}\text { (Comparison of proportions of } \\
\text { mothers }>39 \text { years } \mathrm{P}<0.001 \text { ) }\end{array}$ \\
\hline \multicolumn{4}{|l|}{ Body mass index } \\
\hline Mean BMI at booking $\left(\mathrm{kg} / \mathrm{m}^{2}\right)$ & $\begin{array}{l}25.03 \text { (SD 5.29) } \\
\text { (Range 16-49) } \\
(\mathrm{n}=531)\end{array}$ & $\begin{array}{l}25.8 \text { (SD 6.71) } \\
\text { (Range 15-60) } \\
(n=195)\end{array}$ & 0.10 \\
\hline Lean $<20$ & $42(7.9 \%)$ & $24(12.3 \%)$ & 0.054 \\
\hline Normal $20-29.9$ & 402 (75.7\%) & $131(67.2 \%)$ & \\
\hline Obese $\geq 30$ & 87 (16.4\%) & $40(20.5 \%)$ & \\
\hline
\end{tabular}

\begin{tabular}{|c|c|c|c|}
\hline \multicolumn{4}{|l|}{ Socioeconomic } \\
\hline With social problems & $60 / 548(10.9 \%)$ & $50 / 218(22.9 \%)$ & $<0.001$ \\
\hline Smoking during pregnancy & $114 / 553(20.6 \%)$ & $83 / 226(36.7 \%)$ & $<0.001$ \\
\hline $\begin{array}{l}\text { Drinking Alcohol during } \\
\text { pregnancy }\end{array}$ & $180 / 550(32.7 \%)$ & $75 / 228(32.9 \%)$ & 0.96 \\
\hline Using drugs during pregnancy & $20 / 553(3.6 \%)$ & $12 / 226(5.3 \%)$ & 0.28 \\
\hline
\end{tabular}

sively in the preterm group. Vaginal bleeding, anaemia (haemoglobin $<10.5 \mathrm{~g} / \mathrm{dl}$ ) and proteinuria $(1+$ or more on dipstick, excluding urinary tract infection) occurred in both control and preterm pregnancies, but were significantly increased in the latter. Hypertension with proteinuria (pre-eclampsia) was significantly increased in the preterm group. Hypertension without proteinuria (preg- nancy induced hypertension) was low in both groups. Raised alpha feto protein (AFP) levels were more common in preterm pregnancies, but the incidence was low. Other common complications such as urinary tract infection (UTI), the presence of pathogens in high vaginal swabs (HVS) and the observation of reduced fetal movements were similar in both groups (Table 5). 
Table 3: Previous pregnancies.

\begin{tabular}{|c|c|c|c|}
\hline & $\begin{array}{l}\text { Control ( } \geq 37 \text { weeks' } \\
\text { gestation) }\end{array}$ & $\begin{array}{l}\text { Preterm ( }<35 \text { weeks' } \\
\text { gestation) }\end{array}$ & P value \\
\hline Number of deliveries & 553 & 228 & \\
\hline Gravida 0 & $176(31.8 \%)$ & $62(27.2 \%)$ & 0.20 \\
\hline Gravida $>0$ & $377(68.2 \%)$ & $166(72.8 \%)$ & \\
\hline Para 0 & $239(43.2 \%)$ & $100(43.9 \%)$ & 0.87 \\
\hline Para $>0$ & $314(56.8 \%)$ & $128(56.1 \%)$ & \\
\hline $\begin{array}{l}\text { Number of women with } \\
\text { previous preterm delivery ( } \geq \\
20 \text { and }<37 \text { weeks' gestation). }\end{array}$ & $30(5.4 \%)$ & $58(25.4 \%)$ & $<0.001$ \\
\hline $\begin{array}{l}\text { Termination of pregnancy }(< \\
20 \text { weeks' gestation) }\end{array}$ & $88(15.9 \%)$ & $55(24.1 \%)$ & 0.007 \\
\hline $\begin{array}{l}\text { Spontaneous miscarriage }(< \\
20 \text { weeks' gestation) }\end{array}$ & $30(5.4 \%)$ & $9(3.9 \%)$ & 0.39 \\
\hline
\end{tabular}

Fetal complications were more frequent in the preterm group, especially oligohydramnios, followed by fetal growth restriction and fetal abnormalities (including both structural and chromosomal abnormalities) (Table 5). Preterm premature rupture of the membranes (PPROM) and prolonged rupture ( $>48$ hours) of the membranes were significantly more common in the preterm group.

Multivariable analysis indicated that women with preeclampsia were more likely to have fetal growth restriction; moreover each of the two factors was an effect modifier for the other (supported by significant interaction in logistic regression $\mathrm{P}=0.026$ ). For example, the association of fetal growth restriction with preterm birth was much greater in the presence of pre-eclampsia than in its absence (OR 45.4 [95\% CI 5.8-354.6] versus 3.71 [1.658.33 , respectively). Women with both premature and prolonged rupture of the membranes were the most likely to have oligohydramnios $(\mathrm{P}<0.001)$. Finally, women with vaginal bleeding were more likely to have PPROM or episodes of threatened preterm labour ( $\mathrm{P}<0.001$ for both).

\section{Labour and delivery}

$65 \%$ of women in the control group went into spontaneous labour and $35 \%$ had an elective delivery (caesarean section or induction of labour) indicated for medical or obstetric reasons. In the preterm group 53\% of women had spontaneous labour and $47 \%$ were delivered electively $(P=0.002)$. When the incidence of complications of pregnancy is presented separately in spontaneous and elective deliveries (Figure 1) very different patterns can be observed. Spontaneous preterm deliveries were clearly associated with threatened preterm labour, PPROM and vaginal bleeding. The occurrence of one or more episodes of vaginal bleeding at any stage of pregnancy was relatively common in both term and preterm spontaneous deliveries, but the incidence was significantly higher in the preterm group. By contrast, elective preterm deliveries were strongly associated with anaemia, hypertension and fetal growth restriction (Figure 1). Interestingly, vaginal bleeding, oligohydramnios, PPROM and, to a lesser extent, threatened preterm labour were significantly increased in both spontaneous and elective preterm deliveries.

\section{Neonatal outcome}

Metabolic complications including jaundice, hypoglycaemia and hypothermia were relatively common in both control and preterm groups, although the incidence was significantly higher in the latter (data not shown). Severe complications of prematurity such as respiratory distress (56\%), patent ductus arteriosus (11\%), intracerebral damage $(9 \%)$ and necrotising enterocolitis (4.5\%) were diagnosed almost exclusively in the preterm group. There were 15 stillbirths, 21 neonatal deaths (deaths within 28 days of birth) and 6 postneonatal deaths (after 28 days) in the preterm group compared to only 2 stillbirths, 2 neonatal deaths and 1 postneonatal death in the control group. The main causes of death in the preterm group were severe prematurity, infection and congenital abnor- 
Table 4: Pre-existing medical conditions.

\begin{tabular}{|c|c|c|c|}
\hline & $\begin{array}{l}\text { Control ( } \geq 37 \text { weeks' } \\
\text { gestation) }\end{array}$ & $\begin{array}{l}\text { Preterm (<35 weeks' } \\
\text { gestation) }\end{array}$ & P value \\
\hline $\begin{array}{l}\text { Number of } \\
\text { deliveries }\end{array}$ & 553 & 228 & \\
\hline Anaemia & 103 (18.6\%) & 45 (19.7\%) & 0.72 \\
\hline $\begin{array}{l}\text { Respiratory } \\
\text { problems }\end{array}$ & 89 (16.1\%) & 39 (17.1\%) & 0.73 \\
\hline $\begin{array}{l}\text { Depression/ } \\
\text { Psychiatric } \\
\text { Disease }\end{array}$ & $83(15.0 \%)$ & $50(21.9 \%)$ & 0.019 \\
\hline Hypertension & $51(9.2 \%)$ & 34 (14.9\%) & 0.020 \\
\hline Renal Disease & $34(6.1 \%)$ & 18 (7.9\%) & 0.37 \\
\hline $\begin{array}{l}\text { Sexually } \\
\text { transmitted } \\
\text { diseases }\end{array}$ & $33(6.0 \%)$ & $16(7.0 \%)$ & 0.58 \\
\hline Cardiac disease & $24(4.3 \%)$ & $9(3.9 \%)$ & 0.80 \\
\hline Thyroid Disease & $14(2.5 \%)$ & $3(1.3 \%)$ & 0.29 \\
\hline IVF & $12(2.2 \%)$ & $6(2.6 \%)$ & 0.70 \\
\hline Diabetes & $11(2.0 \%)$ & $3(1.3 \%)$ & 0.52 \\
\hline Hepatitis B & $10(1.8 \%)$ & $5(2.2 \%)$ & 0.72 \\
\hline $\begin{array}{l}\text { Bleeding } \\
\text { disorders }\end{array}$ & $8(1.4 \%)$ & $3(1.3 \%)$ & $>0.99^{*}$ \\
\hline $\begin{array}{l}\text { Uterine } \\
\text { abnormalities }\end{array}$ & $10(1.8 \%)$ & $14(6.1 \%)$ & 0.001 \\
\hline $\begin{array}{l}\text { Cervical } \\
\text { incompetence/ } \\
\text { cervical suture }\end{array}$ & 0 & $5(2.2 \%)$ & $0.002^{*}$ \\
\hline
\end{tabular}

malities; in the control group deaths were associated with congenital abnormalities.

\section{Discussion}

This manuscript provides information on clinical factors associated with preterm delivery in a tertiary referral hospital in the UK. The study benefits from its relatively homogeneous ethnic population and its setting in a maternity hospital with unified management guidelines in the central delivery suite. Moreover, it highlights the main risk factors that remain associated with preterm birth, and emphasizes the need to promote research into the basic mechanisms of parturition as the best way to 
Table 5: Complications of pregnancy.

\begin{tabular}{|c|c|c|c|}
\hline & $\begin{array}{l}\text { Control ( } \geq 37 \text { weeks' } \\
\text { gestation) }\end{array}$ & $\begin{array}{l}\text { Preterm (<35 weeks' } \\
\text { gestation) }\end{array}$ & P value \\
\hline Number of deliveries & 553 & 228 & \\
\hline \multicolumn{4}{|l|}{ Maternal complications } \\
\hline Threatened preterm labour & $17 / 553(3.1 \%)$ & $126 / 228(55.3 \%)$ & $<0.001$ \\
\hline Vaginal bleeding & $130 / 553(23.5 \%)$ & $117 / 228(51.3 \%)$ & $<0.001$ \\
\hline Anaemia & $53 / 513(10.3 \%)$ & $76 / 224(33.9 \%)$ & $<0.001$ \\
\hline Hypertension with proteinuria & $43 / 514(8.4 \%)$ & $52 / 224(23.2 \%)$ & $<0.001$ \\
\hline Hypertension without proteinuria & $13 / 514(2.5 \%)$ & $4 / 224(1.8 \%)$ & 0.54 \\
\hline Urinary tract infection & $56 / 514(10.9 \%)$ & $35 / 224(15.6 \%)$ & 0.072 \\
\hline HVS B Strep. & $26 / 514(5.1 \%)$ & $12 / 224(5.4 \%)$ & 0.87 \\
\hline HVS Other organisms & $70 / 514(13.6 \%)$ & $35 / 224(15.6 \%)$ & 0.47 \\
\hline Hyperemesis & $16 / 514(3.1 \%)$ & $3 / 224(1.3 \%)$ & 0.16 \\
\hline Gestational Diabetes & $14 / 514(2.7 \%)$ & $4 / 224(1.8 \%)$ & 0.45 \\
\hline Late booker & $16 / 513(3.1 \%)$ & $8 / 223(3.6 \%)$ & 0.74 \\
\hline High Down's Risk & $16 / 513(3.1 \%)$ & $7 / 224(3.1 \%)$ & $>0.99$ \\
\hline Raised AFP & $4 / 513(0.8 \%)$ & $6 / 224(2.7 \%)$ & $0.075^{*}$ \\
\hline \multicolumn{4}{|l|}{ Fetal complications } \\
\hline Reduced fetal movements & $140 / 514(27.2 \%)$ & 76/224 (33. 9\%) & 0.066 \\
\hline Oligohydramnios & $49 / 514(9.5 \%)$ & $65 / 224(29.0 \%)$ & $<0.001$ \\
\hline Fetal growth restriction & $12 / 514(2.3 \%)$ & $41 / 224(18.3 \%)$ & $<0.001$ \\
\hline Large for dates & $27 / 514(5.3 \%)$ & $8 / 224(3.6 \%)$ & 0.32 \\
\hline Fetal abnormalities & $14 / 553(2.5 \%)$ & $15 / 228(6.6 \%)$ & 0.007 \\
\hline \multicolumn{4}{|l|}{ Other complications } \\
\hline $\begin{array}{l}\text { Preterm premature rupture of } \\
\text { membranes }\end{array}$ & $5 / 553(0.9 \%)$ & $100 / 228(43.9 \%)$ & $<0.001$ \\
\hline Prolonged rupture of membranes & 49/553 (8.9\%) & $49 / 228(21.5 \%)$ & $<0.001$ \\
\hline
\end{tabular}

*Two-tailed Fisher's Exact test 
develop effective management for spontaneous preterm labour.

In our predominantly Caucasian population, teenage pregnancies were not significantly associated with preterm birth; however, our data confirm that older mothers have an increased risk of preterm delivery [12,13]. A low $\mathrm{BMI}$ is associated with increased risk of spontaneous preterm birth [14] and this was reflected in our population. Previous preterm delivery is a strong risk factor for subsequent preterm birth, with a five fold higher rate of previous preterm delivery in the preterm compared to the control group; this indicates that maternal factors are important, however the mechanism remains unclear. A history of preterm delivery has long been recognised as a strong risk factor for subsequent preterm birth [9] and is the basis for most risk scoring systems [15]. Moreover, our data confirm that hypertension and fetal growth restriction are major predisposing factors for elective preterm delivery $[7,16]$.

Episodes of threatened preterm labour were strongly associated with spontaneous preterm deliveries. Thus, spontaneous preterm labour is characterised by remarkable uterine hyperactivity. The mechanism requires further investigation but it probably results from increased sensitivity of the uterus to stimulatory agonists such as oxytocin, prostaglandins or other endogenous mediators [1], as well as a premature loss of inhibitory pathways involving myometrial ion channels [17]. We have recently shown that spontaneous preterm labour is associated with increased GTP bound RHO proteins in myometrial tissue, a pathway for enhanced uterine contractility through 'calcium sensitization'[18]. Uterine contractions are the most common presenting sign of preterm labour but in a high percentage of women the contractions stop without the need for tocolytic treatment. Separating imminent spontaneous preterm labour from recurrent but transient episodes of uterine contractions remains a major clinical challenge.

Bleeding in pregnancy was strongly associated with both spontaneous and elective preterm deliveries. Women with vaginal bleeding have an increased risk of induction of labour and caesarean section and the condition is associated with other pregnancy complications such as PPROM, oligohydramnios and fetal growth restriction [19]. The mechanism by which intrauterine bleeding may lead to spontaneous preterm labour is not known, but it has been proposed that thrombin activation in the decidua leads to uterine contractions [20,21]. Moreover thrombin increases matrix metalloproteinase activity in the fetal membranes providing a link between intrauterine bleeding and rupture of the membranes $[21,22]$.

Anaemia is one of the most common nutritional problems in pregnant women throughout the world and, after smoking, is the most important preventable risk factor for preterm birth. Our data show that even moderate anaemia $(<10.5 \mathrm{~g} / \mathrm{dl})$ in pregnancy is associated with preterm birth and this agrees with observations in other tertiary referral hospitals [23]. Ascending intrauterine infection is often quoted as a pathogenic mechanism for preterm labour [7], however in our survey the proportion of women with bacterial pathogens in high vaginal swabs was similar in the control and preterm groups.

Preterm babies continue to die in the perinatal period or have severe neonatal complications which predispose to a high incidence of neurodevelopmental impairments and sensory deficits. The early administration of glucocorticoids to the mother and impressive advances in neonatal care have steadily improved neonatal survival rates over the past three decades; however it is unrealistic to expect that improvements in neonatal intensive care will decrease neonatal mortality and the sequelae of prematurity much further [24]. The onus is now on understanding the causes and mechanisms of parturition, so that spontaneous preterm labour can be prevented and preterm birth is only allowed to happen electively for the benefit of the mother and her baby [25]. The proportion of elective preterm deliveries in our survey is considerably higher than in similar UK and European hospital populations in the 1970s and 1980s [6,26]. This reflects a growing confidence among young obstetricians that justified intervention in preterm pregnancies results in good obstetric and neonatal outcome, but significant morbidity should not be forgotten.

This study has limitations because it has surveyed a population of several hundred women in a single tertiary hospital. The factors associated with preterm birth would be better addressed through prospective study of a very large geographical cohort. Furthermore, we believe that over the next decade epidemiological data will be supplemented by advances in uterine physiology and maternofetal endocrinology which will improve our understanding of human parturition and help devise successful strategies to prevent preterm labour.

\section{Conclusions}

The data from this study show that more than $50 \%$ of preterm births follow spontaneous preterm labour and further research to clarify the mechanism by which risk factors such as increased uterine contractility, premature rupture of the membranes and uterine bleeding result in preterm labour will be clearly beneficial. Moreover, it is important to address the major causes of elective preterm delivery, namely hypertensive disorders and intrauterine growth restriction. This may be achieved through the discovery of the aetiology of pre-eclampsia and a better understanding of the control of fetal growth and placental function. The reduction of spontaneous preterm labour is 


\section{Complications of pregnancy in deliveries following spontaneous labour}

Percentage of deliveries affected

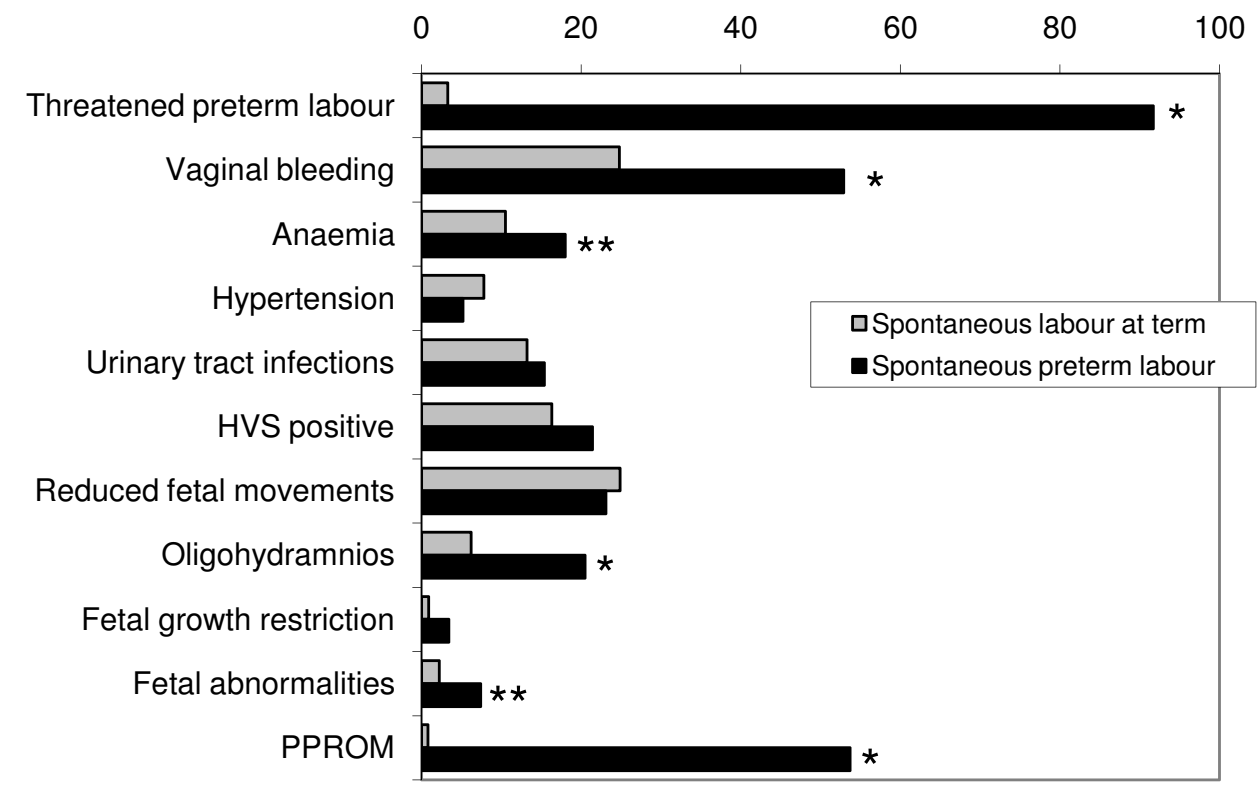

\section{Complications of pregnancy associated with elective deliveries}

\section{Percentage of deliveries affected}

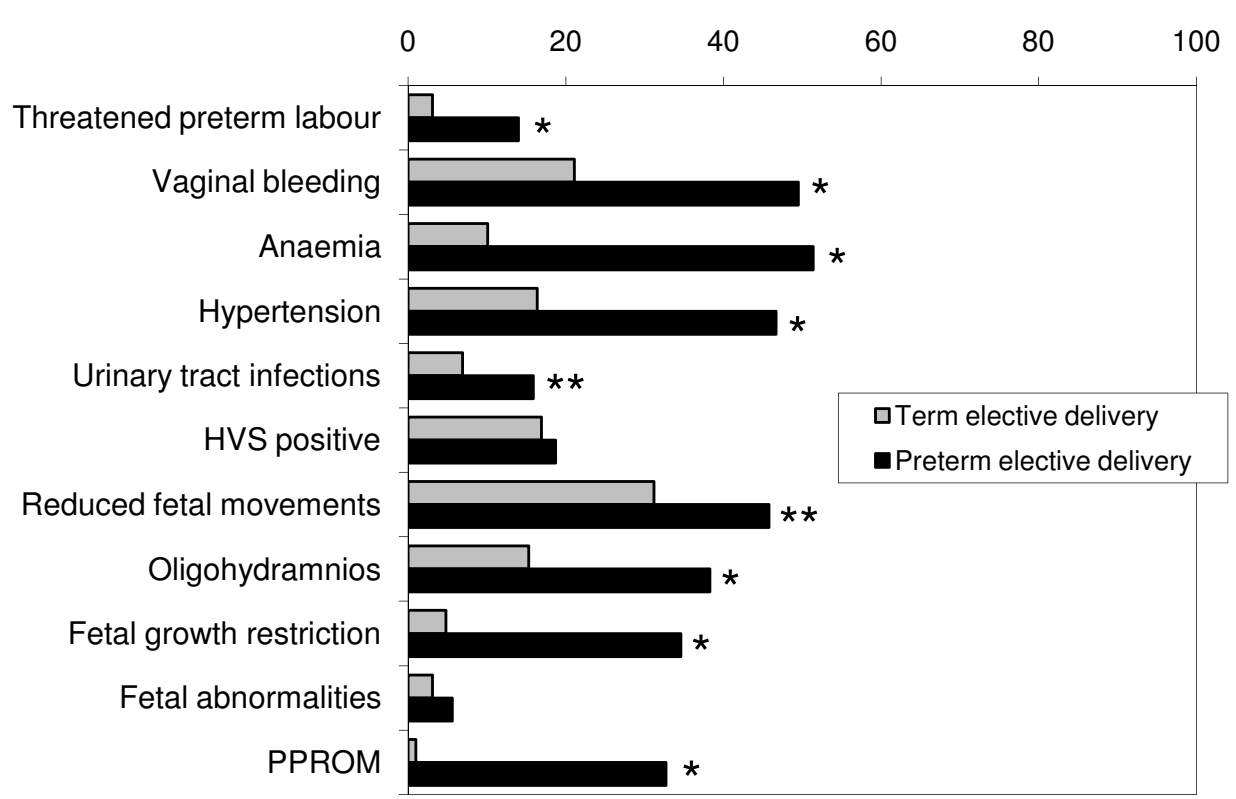

Figure 1 Complications of pregnancy in spontaneous and medically indicated elective preterm deliveries (23-35 weeks' gestation) compared with spontaneous and elective term controls ( $\geq 37$ weeks' gestation). HVS: high vaginal swab. PPROM: preterm premature rupture of the membranes. Significant differences: ${ }^{*} p<0.001 ;{ }^{* *} p<0.05$. 
a realistic aim; however our lack of knowledge of the process of labour is a major handicap in devising effective strategies. It is essential to promote research into the physiological and physiopathological pathways that increase uterine activity during pregnancy. The combination of laboratory and clinical research will provide the necessary breakthroughs to improve the prevention of preterm birth.

Competing interests

The authors declare that they have no competing interests.

\section{Authors' contributions}

WY: Contributed to preparation and analysis of the data. AMD: Substantial contribution to acquisition of data. LC: Substantial contribution to analysis of the data. LPH: Contributed to design of the study and statistical analysis of the data. SMS: Contributed to clinical interpretation of the data and writing of the manuscript. ALB: Design of the study and writing of the manuscript.

All authors have read and approved the final manuscript.

\section{Authors' information}

WY: MSc. PhD student, Department of Clinical Science at South Bristol (Obstetrics and Gynaecology). University of Bristol. AMD: Registered Midwife, Department of Obstetrics and Gynaecology, St Michael's Hospital, Bristol. LC: MSc. Research associate, Department of Social Medicine, University of Bristol. LPH: PhD, CStat, Senior Lecturer in Medical Statistics, Dept of Clinical Sciences at South Bristol. University of Bristol. SMS, MD, FRCOG, Consultant Obstetrician, University Hospitals Bristol, Obstetrics and Gynaecology, St Michael's Hospital. ALB, MD, D Phil, Professor of Human Reproductive Biology, Department of Clinical Science at South Bristol (Obstetrics and Gynaecology). University of Bristol.

\section{Acknowledgements}

The authors are members of the European Parturition Group http:// www.bris.ac.uk/clinicalsciencesouth/eupg/

This research was supported through a SAFE Network of Excellence Bursary (WY) and by Wellbeing of Women.

\section{Author Details}

1 University of Bristol, Department of Clinical Science at South Bristol (Obstetrics and Gynaecology), St Michael's Hospital, Southwell St. Bristol, BS2 8EG. UK, 2University of Bristol, Department of Social Medicine, Canynge Hall, Whiteladies Road, Bristol, BS8 2PR. UK, 3University of Bristol, Dept of Clinical Sciences at South Bristol, Institute of Child Life and Health, Education Centre, Upper Maudlin Street, Bristol, BS2 8AE. UK and 4 University Hospitals Bristol, Obstetrics and Gynaecology, St Michael's Hospital, Southwell St. Bristol, BS2 8EG. UK

Received: 6 April 2010 Accepted: 28 April 2010

Published: 28 April 2010

\section{References}

1. López Bernal A: Mechanisms of labour--biochemical aspects. Bjog 2003, 110(Suppl 20):39-45.

2. Tucker J, McGuire W: Epidemiology of preterm birth. Bmj 2004, 329:675-678.

3. Wen SW, Smith G, Yang Q, Walker M: Epidemiology of preterm birth and neonatal outcome. Semin Fetal Neonatal Med 2004, 9:429-435.

4. Martin JA, Kung HC, Mathews TJ, Hoyert DL, Strobino DM, Guyer B, Sutton SR: Annual summary of vital statistics: 2006. Pediatrics 2008 121:788-801.

5. Beck S, Woijdyla D, Say L, Betran AP, Merialdi M, Requejo JH, Rubens C, Menon R, Van Look PF: The worldwide incidence of preterm birth: a systematic review of maternal mortality and morbidity. Bull World Health Organ 2010, 88:31-38.

6. Rush RW, Keirse MJ, Howat P, Baum JD, Anderson AB, Turnbull AC Contribution of preterm delivery to perinatal mortality. British medical journal 1976, 2:965-968.

7. Goldenberg RL, Culhane JF, lams JD, Romero R: Epidemiology and causes of preterm birth. Lancet 2008, 371:75-84.
8. Langhoff-Roos J, Kesmodel U, Jacobsson B, Rasmussen S, Vogel I: Spontaneous preterm delivery in primiparous women at low risk in Denmark: population based study. Bmj 2006, 332:937-939.

9. Bakketeig LS, Hoffman HJ, Harley EE: The tendency to repeat gestational age and birth weight in successive births. Am J Obstet Gynecol 1979, 135:1086-1103

10. lams JD, Stilson R, Johnson FF, Williams RA, Rice R: Symptoms that precede preterm labor and preterm premature rupture of the membranes. Am J Obstet Gynecol 1990, 162:486-490.

11. Burguet A, Kaminski M, Abraham-Lerat L, Schaal JP, Cambonie G, Fresson J, Grandjean H, Truffert P, Marpeau L, Voyer M, et al.: The complex relationship between smoking in pregnancy and very preterm delivery. Results of the Epipage study. Bjog 2004, 111:258-265.

12. Schempf AH, Branum AM, Lukacs SL, Schoendorf KC: Maternal age and parity-associated risks of preterm birth: differences by race/ethnicity. Paediatric and perinatal epidemiology 2007, 21:34-43.

13. Hall MH, Danielian P, Lamont RL: The importance of preterm birth. In Preterm labor Edited by: Elder MG, Romero R, Lamont RL. New York: Churchill Livingstone; 1997:1-28.

14. Hendler I, Goldenberg RL, Mercer BM, lams JD, Meis PJ, Moawad AH, MacPherson CA, Caritis SN, Miodovnik M, Menard KM, et al:: The Preterm Prediction Study: association between maternal body mass index and spontaneous and indicated preterm birth. Am J Obstet Gynecol 2005 192:882-886

15. Creasy RK: Preventing preterm birth. N Engl J Med 1991, 325:727-729.

16. Steer P: The epidemiology of preterm labour. Bjog 2005, 112(Suppl 1):1-3.

17. Sanborn BM: Relationship of ion channel activity to control of myometrial calcium. J Soc Gynecol Investig 2000, 7:4-11.

18. Lartey J, Smith M, Pawade J, Strachan B, Mellor H, Lopez Bernal A: UpRegulation of Myometrial RHO Effector Proteins (PKN1 and DIAPH1) and CPI-17 (PPP1R14A) Phosphorylation in Human Pregnancy Is Associated with Increased GTP-RHOA in Spontaneous Preterm Labor. Biol Reprod 2007, 76:971-982

19. Chan CC, To WW: Antepartum hemorrhage of unknown origin--what is its clinical significance? Acta Obstet Gynecol Scand 1999, 78:186-190.

20. Elovitz MA, Baron J, Phillippe M: The role of thrombin in preterm parturition. Am J Obstet Gynecol 2001, 185:1059-1063.

21. Erez O, Espinoza J, Chaiworapongsa T, Gotsch F, Kusanovic JP, Than NG, Mazaki-Tovi S, Vaisbuch E, Papp Z, Yoon BH, et al: A link between a hemostatic disorder and preterm PROM: a role for tissue factor and tissue factor pathway inhibitor. J Matern Fetal Neonatal Med 2008, 21:732-744

22. Stephenson CD, Lockwood CJ, Ma Y, Guller S: Thrombin-dependent regulation of matrix metalloproteinase (MMP)-9 levels in human fetal membranes. J Matern Fetal Neonatal Med 2005, 18:17-22.

23. Lone FW, Qureshi RN, Emanuel F: Maternal anaemia and its impact on perinatal outcome. Trop Med Int Health 2004, 9:486-490.

24. Saigal S, Doyle LW: An overview of mortality and sequelae of preterm birth from infancy to adulthood. Lancet 2008, 371:261-269.

25. lams JD, Romero R, Culhane JF, Goldenberg RL: Primary, secondary, and tertiary interventions to reduce the morbidity and mortality of preterm birth. Lancet 2008, 371:164-175.

26. Di Renzo GC, Roura LC: Guidelines for the management of spontaneous preterm labor. J Perinat Med 2006, 34:359-366.

doi: 10.1186/1756-0500-3-119

Cite this article as: Yuan et al., Analysis of preterm deliveries below 35 weeks' gestation in a tertiary referral hospital in the UK. A case-control survey BMC Research Notes 2010, 3:119 